\title{
The disasters of war. On kidney patients in the Ukrainian-Russian war
}

\author{
Piccoli Giorgina Barbara ${ }^{1}$. La Manna Gaetano ${ }^{2}$
}

Published online: 7 March 2022

(c) The Author(s) under exclusive licence to Italian Society of Nephrology 2022

\section{'WAR DOES NOT DETERMINE WHO IS RIGHT- ONLY WHO IS LEFT'}

Quote attributed, among others, to Bertrand Russell and to Winston Churchill.

Spring was around the corner and, after 2 years of the COVID-19 pandemic, the tension in intensive care units was abating and COVID hospitalisation wards were being closed. I was preparing an upbeat editorial on spring, World Kidney Day and the 8th of March, and on the return to normal life, although I knew full well that nothing would ever be the same again.

Only the last part of the sentence holds true today.

When we woke up on February 24th, 2022 to images of war in Ukraine, most of us were stunned, overwhelmed by a sense of unreality. For those who were lucky enough to have been born and raised in Western European countries, where it was our parents and grandparents who remembered World War II, war was something that happens in books, movies, and surreal video games. For as much as we can empathically imagine, our participation lasts but the few hours needed to see a film or read a book. Five days of war, at the time of writing, is an unbelievable amount of time.

Even if the fighting stops soon, as we all hope it will, too many have died, too many have suffered. Too many still will.

Listening to the news on the enormous investments in arms sent to support Ukraine, we initially heard no mention of medicines or hospital supplies. While they are as urgently needed as weapons and need to be sent, only on the first week-end of war did the media actually start talking about humanitarian corridors and help for the refugees. That more money is being spent on missiles than on medicaments is no surprise, however the COVID-19 pandemic proved that it is possible to engage governments in both. However, our

Piccoli Giorgina Barbara

gbpiccoli@yahoo.it

1 Nephrology, Centre Hospitalier Le Mans, Le Mans, France

2 Nephrology, Dialysis and Kidney Transplant Unit, IRCCSSant'Orsola Hospital, Bologna, Italy attention is more on bombs, than on hospitals, on death-dealing devices, more than on wounded soldiers and civilians.

French president Emmanuel Macron said at the beginning of the hostilities that "nothing will ever be as before", a quote being repeated as a mantra these days.

Well, we said the same thing about COVID-19 two years ago. Sadly, we were right.

In addition to concerns about the economy and the cost of gas and energy, which will not only weigh on families' budgets but will also deeply affect the cost of care for our patients, this war should make us reflect on the "disasters of war", to quote Goya, for our kidney patients, a prototype of fragile individuals with a chronic disease, and what can be done to support them and our colleagues ([1], Fig. 1).

The first to be affected will be the sickest: dialysis patients unable to reach their centres, kidney transplant patients who risk remaining without treatment. Let us not forget that a significant contribution to the study of AKI came from the Korean war.

In Ukraine, soldiers and civilians alike are being wounded. Many will need kidney care. Even if the fighting stops now, in the days and months to come the war itself, the disruption of commercial routes, and the imposition of sanctions are likely to induce long-term critical shortages of drugs and medical equipment.

When we say war, we think about wounds. However, in Western Europe about $10 \%$ of the adult population have a kidney disease, and about one in 1000 needs dialysis or lives with a kidney transplant; roughly $5 \%$ of the population has diabetes and $30 \%$ has hypertension, not to mention patients with cancer, and all kinds of chronic diseases.

Disrupting peace is disrupting chronic care, and doing this on both sides. The long-lasting consequences are even more difficult to imagine.

The word we most often hear and read at present is crisis. Health crisis, humanitarian crisis, economic crisis, relational crisis, an education crisis that will affect the lives of our youth, the COVID-19 crisis that has left the elderly isolated and lonely, and many other crises. We lack a clear idea of the extent of these problems and are unable to predict what their consequences will be. We only know that they are the 


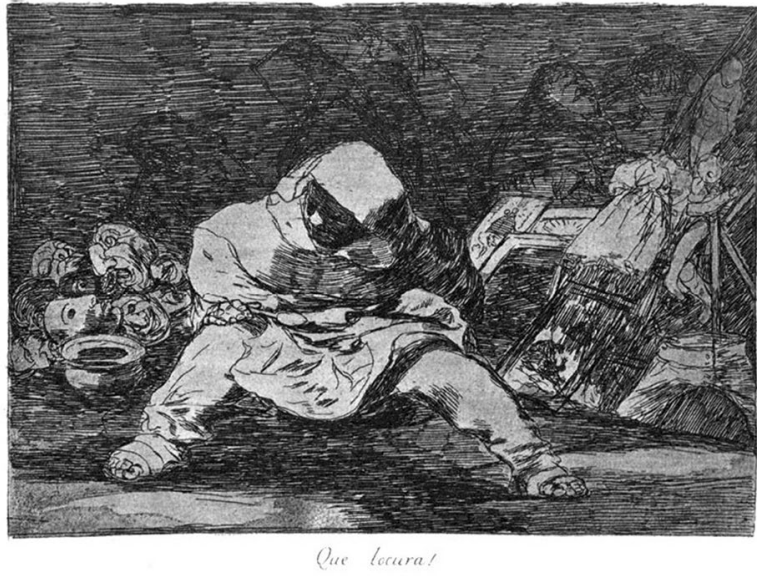

Fig. 1 Francisco Goya. The Disasters of War, Plate 68. What Madness!. The Disasters of War (Spanish: Los Desastres de la Guerra) is a series of 82 prints created between 1810 and 1820 by Francisco Goya (1746-1828). Goya was a court painter, and this impressive series of prints was only published almost 35 years after his death (Source of the image: wikicommons [1])

expression of a series of events that somehow have to do with our choices: insensitivity towards human life, towards ecosystems, towards the weakest. And what frightens us most is how rapidly we are being forced to become aware of these crises and come to grips with them. We, as physicians, have this ultimate responsibility: supporting the weakest, in this case those whose health is deteriorating. It is our duty to try to ensure everyone's right to healthcare. It is a good that is recognized as essential by the United Nations, the European Community and in the constitutions of all our nations. This is the title of the 2022 World Kidney Day: "Kidney Health for All" [2]. No doubt that we are not fulfilling this now.

As physicians we want to ensure every means of support, including guaranteeing corridors of care for patients who need it. Beyond any political or tactical evaluation, our proposal is to be able to share the burden of needs, being willing to accept patients or provide assistance to Ukrainian colleagues who deem our small efforts useful.

What can small, independent, scientific journals, such as the Journal of Nephrology and the Giornale Italiano di Nefrologia do in this context?

First of all, we should remember that we are all involved.

Secondly, we need to give space to the colleagues directly involved in this terrible situation, in Ukraine and in
Russia, enabling them to convey their experiences and have their voices heard. This is not only the support we owe; it is a way to concretely understand how we can help.

Thirdly, we ought to ask experts on disaster nephrology to write articles clarifying the long list of the disruptive effects on care, and especially on kidney care, that we have to expect, and should face as a united nephrology society, from the battlefield and from restrictions, on both sides involved in the conflict. Professor Raymond Vanholder and doctor Daniel Gallego and Professor Mehmet Sukru Sever are now writing for us, and we praise their commitment: their help is important in guiding our efforts [3].

As editors of free, independent journals, we need to stand up for freedom and justice without biased views; as a scientific-medical community we have to do our best to understand what is needed and how to provide support.

As physicians, human beings engaged in the fight against diseases, hope is one of our weapons. We have to hope that this war ends, and that this terrible experience helps us do better in the future, because in this troubled world there is always room for improvement.

\section{Declarations}

Conflict of interest The authors declare no conflict of interest.

Ethical statement No ethical approval is requested for this kind of editorial paper.

\section{References}

1. https://commons.wikimedia.org/wiki/File:Plate_68_from_\% 27The_Disasters_of_War\%27_(Los_Desastres_de_la_Guerr a)-_\%27What_madness!.\%27_(Que_locura!)_MET_DP817464. jpg? uselang=it

2. 2022 Campaign - World Kidney Day. https://www.worldkidne yday.org/2022-campaign/. Accessed 5 Mar 2022

3. Vanholder R, Gallego D, Sever MS (2022) Wars and kidney patients: a statement by the European Kidney Health Alliance related to the Russian-Ukrainian conflict. J Nephrol. https://doi. org/10.1007/s40620-022-01301-4

Publisher's Note Springer Nature remains neutral with regard to jurisdictional claims in published maps and institutional affiliations. 